\title{
Cultural Dynamics
}

http://cdy.sagepub.com/

\section{Ethnographies of Activism: A Critical Introduction}

Sharad Chari and Henrike Donner

Cultural Dynamics 2010 22: 75

DOI: $10.1177 / 0921374010380887$

The online version of this article can be found at:

http://cdy.sagepub.com/content/22/2/75

\author{
Published by: \\ (9)SAGE \\ http://www.sagepublications.com
}

Additional services and information for Cultural Dynamics can be found at:

Email Alerts: http://cdy.sagepub.com/cgi/alerts

Subscriptions: http://cdy.sagepub.com/subscriptions

Reprints: http://www.sagepub.com/journalsReprints.nav

Permissions: http://www.sagepub.com/journalsPermissions.nav

Citations: http://cdy.sagepub.com/content/22/2/75.refs.html 


\title{
Ethnographies of Activism: A Critical Introduction
}

\section{Sharad Chari and Henrike Donner}

\section{Ethnography and Activism: Oxymoron or Opportunity?}

\begin{abstract}
Ethnography is like much else in the social sciences ... It is a multi-dimensional exercise, a coproduction of social fact and sociological imagining, a delicate engagement of the inductive with the deductive, of the real with the virtual, of the already-known with the surprising, of verbs with nouns, processes with products, of the phenomenological with the political. (Comaroff and Comaroff, 2003: 172)

Forgotten places ... have experienced the abandonment characteristic of contemporary capitalist and neoliberal state reorganization ... [H] ow can people who inhabit forgotten places scale up their activism from intensely localized struggles to something less atomized and therefore possessed of a significant capacity for self-determination? How do they set and fulfill agendas for life-affirming social change-whether by seizing control of the social wage or by other means? (Gilmore, 2008: 31)
\end{abstract}

In what ways might the work of ethnography, conceived of in this inclusive and multidimensional way by Jean and John Comaroff, prove useful for reimagining the multi-scalar work of building activist solidarity, pace Ruth Wilson Gilmore? Our comments emerge from a sequence of workshops on 'Ethnographies of Activism' organized by us at the London School of Economics in 2007 and 2008, the second of which was focused on revising papers for this double special issue of Cultural Dynamics. The two of usDonner, an anthropologist of South Asia, and Chari, a geographer of India and South Africa-came together through the question of whether it might be possible to think through the problems of ethnographic research on activism with a specifically left or 'progressive' focus. In the process of engaging this problem, we recognized disciplinary constraints and possibilities in our attempts to harness ethnography as a transdisciplinary and transformative practice. We found that thinking across ethnography and progressive activism involves transgressing disciplinary boundaries to address complexity and universality (Gibbons et al., 1994; Hallward, 2001).

We realized that one response could be that the 'left' is rife with tensions and that our call for papers was too restrictive. However, we persisted in making the case for thinking

Corresponding author:

Sharad Chari,

Email: s.chari@Ise.ac.uk 
with progressive traditions and practices in and across various sites, and invited contributions to the workshop that would foreground the difficult work of forging solidarity, for ethnographers and activists alike. As Charles Hale (2008: 2) argues, activist scholarship is often called into question within the academy when it is posed in terms that are 'overly celebratory or sanguine' rather than in relation to actual confrontations with complexity and contradiction. Critical ethnography involves similar confrontation with complexity and contradiction, in its inductive and deductive moments.

However, we go further in our renovation of ethnography than the call for a reflexive ethnography critical of power relations and inequalities inherent in research with 'others'. George Marcus suggests that different types of reflexivity indicate significant differences in the way people conceive of ethnography as a political project (Marcus, 1998). The most popular form of reflexivity is 'self critique, the personal quest, playing on the subjective, the experimental, and the idea of empathy'; some contributors to our first 'Ethnographies of Activism' Workshop, like Shannon Walsh, Sami Hermez, Kamala Visweswaran and Richa Nagar drew on this form. Marcus distinguishes this from a second form he refers to as 'sociological' reflexivity, which seeks objectivity through reflection on the conditions of research; several contributors also engaged with this form, including Laura Liu, Naisargi Dave, Dave Featherstone and Hugo Gorringe. Marcus also writes of 'anthropological' reflexivity, based on the point of view of an 'other', and 'feminist' reflexivity, based on a recognition of intersectionality (Marcus, 1998: 193); most contributors to our workshops engaged with these issues in one way or the other, if not necessarily in these terms. In the first workshop, Peter Hallward made a provocative argument against an anthropological reflexivity that seeks an othered point of view as the foundation of knowledge about activism; rather, he explores the work of Haitian activists in forging a universalizing will that is post-colonial without becoming parochial.

In various ways, these forms of reflexivity constitute a critical ethnography engaged with power relations in research, in the broader context, and in writing. As D. Soyini Madison puts it, critical ethnography:

. . . begins with an ethical responsibility to address processes of unfairness or injustice within a particular lived domain. By ‘ethical responsibility’ I mean a compelling sense of duty and commitment based on moral principles of human freedom and well-being, and hence a compassion for the suffering of living beings. The conditions for existence within a particular context are not as they could be for specific subjects; as a result, the researcher feels a moral obligation to make a contribution toward changing those conditions toward greater freedom and equity. The critical ethnographer also takes us beneath surface appearances, disrupts the status quo, and unsettles both neutrality and taken-for-granted assumptions by bringing to light underlying and obscure operations of power and control. Therefore, the critical ethnographer resists domestication and moves from 'what is' to 'what could be'. (Madison, 2005: 5)

In other words, critical ethnography requires thinking through complexity and contradiction in a way that conveys the problems faced in living through the situation. Indeed, any attempt to grasp one's context so as to seek to transform it involves a moment of critical reflection on experience. In this sense, there is an affinity between critical ethnography — or ethnography that seeks not just to describe but to transcend existing inequalities - and what we interchangeably call left or progressive praxis. Once we see left solidarity as a problem rather than a social fact, critical ethnography and activism can 
be thought of as parallel, related and potentially supportive endeavours. Indeed, longterm commitment to specific sites, issues or communities has often forced scholars to engage with social justice issues and struggles. Several participants in our workshops, including Ruth Wilson Gilmore, Biju Mathews, David Graeber, Peter Hallward, Massimo de Angelis, Richa Nagar and Laura Liu have had such long-term commitments, and have drawn on a variety of forms of evidence and engagement beyond what is conventionally thought of as ethnography. More importantly, these and others at our workshops would concur with Philippe Bourgois's call to go beyond witnessing events, to actively question the reproduction of social inequality:

Ethnographers cannot presume to speak on behalf of the worlds socially excluded, but writing against inequality is imperative. Denouncing injustice and oppression is not a naïve, oldfashioned anti-intellectual concern or a superannuated totalizing vision of Marxism. On the contrary, it is a vital historical task intellectually, because globalization has become synonymous with military intervention, market-driven poverty, and ecological destruction. It is impossible to understand what is going on anywhere without paying attention to the power dynamics that shape inequality everywhere. (Bourgois, 2006: pp. x-xi)

The participants in our workshops included scholars of anthropology, geography, philosophy, sociology, women's studies, economics and politics. We welcomed a variety of critical engagements with questions of activist research and solidarity. There are three main areas we think through in introducing these two special issues on Ethnographies of Activism. First, we frame an agenda beyond a focus on 'old' vs 'new' issues, or classical vs new social movements, to a focus on the complexities of activist praxis and to a practice-based understanding of left activism as concerned with 'life affirming social change'. Second, we turn to questions of identity, representation and political imagination, as these issues inform the problem of solidarity central to both activism and ethnography. Third, we return to the question of critical ethnography as a relational and reflexive engagement with the production of solidarity to expand the domain of life-affirming social change. We share the view with several thinkers that solidarity emerges through engagement with difference, and is never guaranteed. The papers we assemble here and in the subsequent issue speak in varied ways to this central problem.

\section{From 'Old vs New Social Movements' to the Critique of Activist Praxis}

Thinking beyond binaries has pushed us to consider continuities across time, space and domains of the social. As Charles Tilly convincingly argues, social movements marked as 'old' and 'new' share many commonalities in organizing efforts and claims in a campaign, in repertoires of political action and in seeking to constitute recognizable publics with stable conceptions of unity and commitment (Tilly, 2004: 53). However, distinctions between 'old' and 'new' movements also carry other baggage. The confluence of critiques we call 'post-1968,' drawing on feminist, queer, anti-racist, post-colonial, environmental and other struggles, question ways in which activist publics were conventionally defined, established, maintained and transformed for new struggles. 'Old' movements too often 
presumed to understand practices and points of view of constituencies they claimed to represent, such as the 'working class' or the 'Third World woman'. This discounted the specific repertoires of contention devised by various subalterns, and as Laura Liu puts it in her contribution, the 'grassroots epistemologies' emerging from their praxis.

Post-1968 activists and critics were often caught between the importance of establishing new publics and of engaging existing ones. These challenges often hinged on rethinking class solidarities outside conventional situations, and across other modalities than conventionally raced and gendered 'working-class' concerns. Allegedly new forms of activism often sought to link the politics of representation to class politics in new ways, allowing different kinds of activist styles and collectives to emerge. The keynote speaker at our second workshop, Geoff Eley, writes about precisely this challenge in radical thought, particularly in the disciplinary practices of history. His rendition of shifts from social history to cultural history to what he calls 'the history of the social' hinge precisely on what we have considered as the broad challenge of thinking ethnographically, and critically, about the terms and practices that constitute social worlds (Eley, 2005). While Shukaitis and Graeber (2007) argue that many of the critical insights after 1968 were limited to the US academy, with its attendant limits and contradictions, Eley's thoughts connect a recalibration of what counts as defensible history ('good history') within a wider world of political possibility in the late 1960s:

[I]ntellectual developments conjoined with a series of political departures. The radical politics of the sixties were inseparable from the historiographical story. The breakthrough to social history was unimaginable without the sense of political possibility beckoning during the later 1960s, the excitement of a new political world beginning to open up. For me, at least, thinking these things together was an essential part of the time. Good history meant good politics, just as bad politics produced bad history. All of this ended up to a particular sensibility, which is also profoundly the sensibility of 1968. (Eley, 2005: 59)

Eley's rendition of 1968 focuses on the emergence of political imaginations and repertoires in an expansive moment of progressive politics that has in many ways and on many fronts become strongly circumscribed by militarism, neoliberalism and state racism in our time. We therefore turn to '1968' not in the vein of nostalgia or regret, but as a critical reminder of the multiplicity of movements also today; of the intimate links between knowledge and its broader conditions of production; and of the partiality of facts and the importance of critical resistance across the multiple and intersecting processes that constitute social life. Post-1968 movements drew on these sensibilities in reconceiving what Plummer (2009) calls 'subterranean traditions' suppressed in official accounts. Subterranean traditions provided resources for the reimagining what a 'progressive' or 'left' activism should stand for, drawing from the experience of communities of practice rethinking ethnicity, gender, queer sexualities, radical livelihoods, environmentalism, anti-war activism, bohemian or art collectives and religious groups (Plummer, 2009: 52).

In many instances this moment was perceived as a demand from 'other' voices demanded to be heard, particularly when they questioned existing representations of movements, constituencies and ways of being an activist. However, this moment also encouraged all sorts of cross-pollination: for instance, feminism came to discuss labour 
struggles, environmentalists increasingly engaged in peace movements and 'Third World' solidarity, and anti-racists came to environmental issues to question the ecology of segregation. Shifting alliances triggered analytical shifts: certain conventions of representation were revealed as problematic and exclusive, and scholars struggled to redefine relationships between theory and practice, analysis and democratic politics, personal and political involvement. Perhaps most importantly, issues were delinked from 'natural' constituencies. We conceive of the set of papers to follow very much in this vein of creative cross-pollination.

Hence, several fronts of post-1968 politics challenge received wisdom in a variety of ways, and call for thinking beyond the dichotomies of old vs new movements. Feminist movements were often at the forefront in challenging gender inequalities in healthcare, welfare and other fronts of political and economic inequality while also engaging in the politics of knowledge and representation, sometimes drawing from anti-racist and postcolonial criticism (Amos and Parmar, 1984; Anzaldua, 1981; Carby, 1982; Hull et al., 1982; Mohanty et al., 1991; Narayan, 2000; Southall Black Sisters, 1990). More recently, environmental justice activism has become an arena of critically renovation of earlier critical work on race, class, gender and development politics (Guha and Martinez-Allier, 1997; Pulido, 1996; Peet and Watts, 2004).

Feminism and anti-racism have had parallel and sometimes intersecting histories of renovating older concerns in contemporary engagements with subjectivity, discourse, and cultural politics, in which the production of solidarity is seen as an active and ongoing challenge. As one instance, Daniel Cornfield argues that the new social unionism in the North-'labor inclusive coalitions' in US and European cities-point to a new moment of labour activism which begins with the premise that workers have multiple social identities and therefore ought to engage in coalitional politics across multiple institutional domains (Turner and Cornfield, 2007: 236-44). The refusal to separate workplace politics from identity politics is grounded in histories of class struggle, through which capital has undermined labour solidarity through the segregation of sites and issues. Crucially, the resurgence of social unionism in Euro-American contexts rests on building coalitions with non-labour groups, to work through multiple identifications/ affiliations, to bridge documented and undocumented status and so on (Fantasia and Voss, 2004; Turner and Cornfield, 2007). Indeed, activists in labour movements have learnt what feminists and anti-racists in Northern and Southern contexts have long argued for: the importance of linking domains from the intimate to the social, and of renovating and making critical the range of 'community' institutions that might otherwise be used for reactionary ends (Joseph, 2002). In the following section, we turn briefly to questions of political imagination, identification and representation that have opened up in this time of rethinking a variety of political truisms.

\section{Political Imagination, Identification and Representation}

There are no natural points of departure in unpacking progressive political imaginations. Scholars across the disciplines have been forced to engage the implications of Gayatri Spivak’s (1988) infamous rhetorical question, 'Can the Subaltern Speak?' For ethnographers, the challenge has not so much been to listen, as some mistaken critics have 
responded, but rather to face the politics of witnessing, aware of the many forms of disclosure and dissimulation at play in forging and questioning solidarities (Visweswaran, 1994). For those attentive to the ethnographic elements of Spivak’s argument, political identification can be made in multiple ways, through embodied cues and gestures that can only be understood in historical and practical context. Spivak's argument also calls for a more patient mode of engagement with subjects, and a suspension of the rush to identify or represent (Mahmood, 2005).

In this vein, Asale Angel-Ajani reflects on her work with female prisoners of African origin in Italy to argue for a suspension of judgement in the process of representation while collecting testimonies (Angel-Ajani, 2006: 86-7). While others question the veracity of her subjects' accounts, pressing Angel-Ajani about her research methods in collecting evidence, she refuses the ongoing stigma that is attached to 'the criminal', asking instead that we reconsider the scholar's participation in the process of bearing witness (Angel-Ajani, 2006: 86-7.) Shannon Speed writes about her positionality in recalling events following a massacre by pro-government paramilitary forces in Chiapas, Mexico (2006). Speed situates her insights as a feminist, indigenous-rights activist and new mother, as she refuses to simplify the Zapatista's gender politics in her fieldwork (Speed, 2006: 185). In this case, retrospective witnessing and awareness of the politics of position confirm a commitment to ethnographic complexity. We revisit these concerns in several contributions to our special issues.

The essays in Sanford and Angel-Ajani's edited volume on 'engaged observers' engage with problems of identification and representation that emerge from the anthropologists' work with respect to activism and advocacy (Sanford and Angel-Ajani, 2006; Warren, 2006). The question of what constitutes 'engagement' is a broad one. One of the fictions that has to be dispelled is the notion that the state sits outside the boundaries of engagement. Indeed, activist and advocacy knowledge have been fundamentally shaped in relation to state projects, whether through tribunals and fact-finding missions, or in practices of expert witnesses and referees. Engagement is now part and parcel of official academic politics; it is required in grant applications, and it often stretches the boundaries between voluntary and involuntary participation, putting activist researchers on the left in new states of vulnerability (Sundar, 2004).

Scholars engaged in projects of restitution of various sorts confront questions of political representation in specific ways, whether in decisions about how to disclose or protect voices, how to limit processes of epistemic violence, or how to prevent the use of ethnographic research for other, less palatable ends. At one limit, representations of 'others' might be drawn into state policies driven by fears of various imagined enemies (Huysmans, 2004). In these various ways, questions of political identification and representation continue to be objects for critical inquiry in new ways in uncertain times.

\section{Critical Ethnography and the Space for Solidarity}

The late Edward Said championed the role of what he called the 'amateur' intellectual, unbeholden to parochial disciplinarity or the instrumental demands of power (Said, cited in Gordon, 1997: 185). Rather than the narrow expertise of the professional intellectual, Said's call is for the amateur to speak truth to power. Lewis Gordon's rejoinder is 
'shouldn't the amateur be one who speaks the truth about power to those who are without power ... and thereby empowers them? Aren't the powerful those who by the luxury of their circumstances find the truth about themselves more a nuisance than a call to moral responsibility?' (Gordon, 1997: 190).

As Johannes Fabian points out, the world is full of amateurs who comment on the nature of truth, as is evident in the Congolese prefix to all narratives: 'story appears, lie appears' (Fabian, 2001: 91). The space of solidarity lies between these variously positioned amateurs who attempt to piece together strategies for navigating landscapes of official dissimulation, to speak about and against power for all those who share in the notion of a common future for all.

As we have argued, feminist ethnography has long wrestled with these problems of forging solidarity (for instance, Davis, 1983; Naples, 2003; Stacey, 1988). However, as Lewis Gordon (1997: 193) argues, political work also involves 'mundane, often boring features of instrumental activity' in maintaining political institutions and responding to right-wing or reactionary violence. Moreover, solidarity implies some kind of relationship of reciprocity with others considered as research participants and political allies (Gordon, 1997: 195; Hale, 2008: 3). Stuart Kirsch (2002: 178) argues that it is the notion of reciprocity that makes activism an extension of anthropological commitment; this is particularly true in work concerning social justice claims of communities in relation to corporations and the state.

Nancy Scheper-Hughes's insightful discussion of how one gets involved has much to say about commitment and solidarity, and she argues that the decision to engage in critical ethnography comes from specific settings (Scheper-Hughes, 2005). Like ScheperHughes, Nandini Sundar became involved in advocacy work following sustained interaction with a marginalized community. Sundar's advocacy work has resulted in sharp confrontation with the state, which raises numerous questions regarding the reciprocity ethnographers can realize in situations of intense state repression (Sundar, 2004).

This work of building solidarity might also be clearer in situations in which agents of social change are identifiable, and where progressive coalitions are already evident (Gilmore, 2008; Pulido, 2006). However, in many situations of stark inequality in which popular grievances take violent and undemocratic form, solidarity with an imagined radical democratic left perspective becomes more difficult, as for instance in the collective work edited by Watts (2009) on the violent environments of the Niger Delta, or the contributions from Chiapas, the US West, and various other landscapes in Peluso and Watts (2001), or from activism in situations of counterinsurgency (Hansen, 2001; Shah and Pettigrew, 2010; Sundar, 2004). Some would argue that, even in less problematic circumstances, binary distinctions between left and right, progressive and reactionary, empowering and disempowering, are Northern impositions, as Saba Mahmood attests in her critique of western feminism in relation to women's involvement in the Mosque Movement in Cairo (Mahmood, 2005). We insist on a critical ethnography of activism that questions such certainties but is also directed towards what Ruth Gilmore in the opening quotation to this introduction calls 'life affirming social change', or forms of activist praxis that seek to limit and combat the conditions that produce social violence (Gilmore, 2008). As part of the group of scholars engaged in research on 'real utopias', Erik Olin Wright sets out conditions for this kind of emancipatory social science: 
[A]ny emancipatory social science faces three basic tasks: elaborating a systematic diagnosis and critique of the world as it exists; envisioning viable alternatives; and understanding the obstacles, possibilities, and dilemmas of transformation. In different times and places one or another of these may be more pressing than others, but all are necessary for a comprehensive emancipatory theory.' (Wright, 2010)

The contributions to these two special issues speak to these tasks in a variety of ways. This issue includes contributions from David Featherstone, Hugo Gorringe, Tilde Rosmer, and Sophie Day and Victoria Goddard.

David Featherstone thinks critically and ethnographically about 18th-century activist networks organized in a Correspondence Society. Drawing on post-national and sociocultural history, Featherstone is concerned with practices that expand democratic possibilities. Much hinges on the way in which Featherstone thinks about the 'articulation' of the political, taking the work of Stuart Hall through a specifically geographical lens. Featherstone's work details the way in which spatial articulations link parochial interests to express new progressive possibilities. Engaging questions of common production and activist solidarity from a quite different space and time, Hugo Gorringe thinks through his research on Dalit or ex-untouchable organizing in the Tamil Nadu state of South India, drawing on a careful comparison of two villages facing broader challenges in different ways. Gorringe engages the intertwined politics of rights and recognition in critically engaging the making of communities of activists, and he is careful in attending to the interplay of actual and symbolic claims and victories. Gorringe's fine-grained ethnography allows us to see everyday practices of organizing, as the movement steers between inclusive and reductionist conceptions of Dalit activism. Tilde Rosmer's article attends to ethical and political tensions emerging from activism academics in Israel. Rosmer shows how identity politics with respect to 'race' complicate the critical stance in Israel's academia, and how the epistemological struggles activists experience have an effect on her own research. Finally, Sophie Day and Victoria Goddard use the work of Hannah Arendt to think across gendered activism emerging from London sex workers and from Argentinian mothers of the disappeared. Day and Goddard ask how activists renovate honour to expand their collective bargaining power and also to mark their presence in the public sphere. The question here, as in some of the other articles, is not so much who becomes an activist as how idioms of political participation are made. In both their cases, Day and Goddard find activists resisting the formalization of their activities, drawing on reductionist identifications as whore or mother respectively to contest politics as usual.

Briefly, the subsequent issue includes contributions from Naisargi Dave, Sami Hermez, Silvia Posocco, Laura Liu and Henrike Donner. Naisargi Dave's paper on lesbian and queer activism in post-colonial Delhi makes a provocative case, following Michel Foucault, for queerness as centrally concerned with ethics. Dave explores the conditions of possibility for various forms of lesbian activism, sensitively engaging their contradictions and confluence, and questioning the processes through which activist practice emerges. Sami Hermez addresses the politics of ethnographic research during his involvement with relief actions in Lebanon, when an acute crisis forced him to engage with the work activists performed in a very practical ways. Hermez finds that constitutes effective activist and academic subjectivities becomes increasingly problematic in the 
course of ethnographic writing. Questions concerning knowledge about activism are central to Silvia Posocco's article, which questions ethnographic knowledge as a form of witnessing in the aftermath of a violent crisis in Guatemala. Drawing on social theory she explores the performative dimensions of ethnography, to radically question what an ethnography of activism is productive of, and how we might think critically about the process of activist memory. Laura Liu's article takes a different approach by turning to the transformative possibilities in immigrant community organizing in New York's Chinatown. Liu thinks critically with what she calls 'migrant epistemology', and with concepts and practices emerging from organizing. Researchers engaging with these terms in struggle find the means for effective ethnographies of activism that connect to community activist strategies to reshape the terms and processes of social domination.

\section{References}

Amos V, Parmar P (1984) Many voices, one chant: black feminist perspectives. Feminist Review 17: 3-19.

Angel-Ajani, A (2006) Expert witness: notes toward revisiting the politics of listening. In: Sanford V, Angel-Ajani A (eds) Engaged Observer: Anthropology, Advocacy and Activism. New Brunswick, NJ: Rutgers University Press, 76-92.

Anzaladua G (ed.) (1981) This Bridge Called My Back: Writings by Radical Women of Color. Watertown: Persephone Press.

Bourgois P (2006) Anthropology and the global state of emergency. In: Sanford V and AngelAjani A (eds) Engaged Observer: Anthropology, Advocacy and Activism. New Brunswick, NJ: Rutgers University Press, pp. ix-xii.

Carby H (1982) White women listen! Black feminism and the boundaries of sisterhood. In: Centre for Cultural Studies (ed.) The Empire Strikes Back: Race and Racism in 70s Britain. London: Hutchinson, 212-35.

Comaroff J, Comaroff J (2003) Ethnography on an awkward scale: postcolonial anthropology and the violence of abstraction. Ethnography 4(2): 147-79.

Davis A (1983) Women, Race, and Class. New York: Vintage Books.

Eley G (2005) A Crooked Line: From Cultural History to the History of Society. Ann Arbor: University of Michigan Press.

Fabian J (2001) Anthropology with an Attitude: Critical Essays. Stanford, CA: Stanford University Press.

Fantasia R, Voss K (2004) Hard Work: Remaking the American Labor Movement. Berkeley, CA: University of California Press.

Gibbons M, et al. (eds) (1994) The New Production of Knowledge: The Dynamics of Science and Research in Contemporary Societies. London: SAGE.

Gilmore RW (2008) Forgotten Places and the Seeds of Grassroots Planning. in Charles R. Hale, ed., Engaging Contradictions: Theory, Politics and Methods of Activist Scholarship. Los Angeles and Berkeley: University of California Press, 31-61.

Gordon LR (1997) Her Majesty's Other Children: Sketches of Racism from a Neocolonial Age. Oxford: Rowman \& Littlefield.

Guha R, Martinez-Allier J (1997) Varieties of Environmentalism: Essays North and South. London: Earthscan.

Hale, CR (2008) Theory, Politics and Methods of Activist Scholarship. Los Angeles and Berkeley: University of California Press.

Hallward P (2001) Absolutely Postcolonial: Writing between the Singular and the Specific. Manchester: Manchester University Press. 
Hansen, TB (2001) Wages of Violence: Naming and Identity in Postcolonial Bombay. Princeton: Princeton. University Press.

Hull GT, Bell Scott P, and Smith B (eds) (1982) All the Women Are White, All the Blacks are Men, But some of Us Brave: Black Women's Studies. New York: Feminist Press.

Huysmans J (2004) Minding exceptions: the politics of insecurity and liberal democracy. Contemporary Political Theory 3(3): 321-33.

Joseph M (2002) Against the Romance of Community. Minneapolis: University of Minnesota Press.

Kirsch S (2002) Anthropology and advocacy: a case study against the campaign of the Ok Tedi Mine. Critique of Anthropology 22(2): 175-200.

Madison DS (2005) Critical Ethnography: Methods, Ethics, Performance. New York: SAGE.

Mahmood S (2005) Politics of Piety: Islamic Revival and the Feminist Subject. Princeton, NJ: Princeton University Press.

Marcus G (1998) Ethnography through Thick and Thin. Princeton, NJ: Princeton University Press. Mohanty CT (1991) Under western eyes: feminist scholarship and colonial discourse. In: Russo A, Torres L (eds) Third World Women and the Politics of Feminism. Bloomington, IN: Indiana University Press, 51-80.

Naples N (2003) Feminism and Method: Ethnography, Discourse Analysis and Activist Research. London: Routledge.

Narayan U (2000) Essence of culture and a sense of history: a feminist critique of cultural essentialism. In: Narayan U, Harding S (eds) Decentering the Center: Philosophy for a Multicultural, Postcolonial and Feminist World. Bloomington: Indiana University Press, 80-100.

Peet R, Watts M (2004) Liberation Ecologies: Environment, Development, Social Movements. London and New York: Routledge.

Peluso N, Watts M (2001) iolent Environments. Ithaca, NY: Cornell University Press.

Plummer K (2009) Subterranean traditions rising: the year that Enid Blyton died. In: Bhambra GK, Demir I (eds) 1968 in Retrospect: History, Theory, Alterity. London: Palgrave, 43-58.

Pulido L (1996) Environmentalism and Economic Justice: Two Chicano Struggles in the Southwest. Tucson, AZ: University of Arizona Press.

Pulido L (2006) Black, Brown, Yellow and Left: Radical Activism in Los Angeles. Berkeley-Los Angeles and London: University of California Press.

Sanford V, Angel-Ajani A (2006) Engaged Observer: Anthropology, Advocacy, and Activism. New Brunswick, NJ: Rutgers University Press.

Scheper-Hughes N (1995) The primacy of the ethical: propositions for a militant anthropology. Current Anthropology 36(3): 409-20.

Shah A, Pettigrew J (eds) (2010) Windows into a Revolution: Ethnographies of Maoism in South Asia. New Delhi: Social Science Press.

Shukaitis S, Graeber D (2007) Introduction. In Shukaitis S, Graeber D (eds) Constituent Imagination: Militant Investigations - Collective Theorisation. Oakland, CA: AK Press, 11-36.

Southall Black Sisters (eds) (1990) Against the Grain, 1979-1989: A Celebration of Survival and Struggle. London: Southall Black Sisters.

Speed S (2006) Indigeneous women and gendered resistance in the wake of Acteal: a feminist activist research perspective. In: Sanford V, Angel-Ajani A (eds) Engaged Observer: Anthropology, Advocacy, and Activism. New Brunswick, NJ: Rutgers University Press, 170-88.

Spivak GC (1988) Can the subaltern speak? In: Nelson C, Grossberg L (eds) Marxism and the Interpretation of Culture. Urbana, IL: University of Illinois Press, 271-313.

Stacey J (1988) Can there be a Feminist Ethnography? Women's Studies International Forum 11(1): 21-7.

Sundar N (2004) Toward an anthropology of culpability. American Ethnologist 31(2): 145-63. 
Tilly C (2004) Social Movements, 1768-2004. Boulder, CO: Paradigm Publishers.

Turner L, Cornfield DB (2007) Labor in the New Urban Battlegrounds: Local Solidarity in a Global Economy. Ithaca, NY: Cornell University Press.

Visweswaran K (1994) Fictions of Feminist Ethnography. Minneapolis: University of Minnesota Press.

Warren K (2006) Perils and promises of engaged anthropology: historical transitions and ethnographic dilemmas. In Sanford V, Angel-Ajani A (eds) Engaged Observer: Anthropology, Advocacy, and Activism. New Brunswick, NJ: Rutgers University Press, 213-27.

Watts MJ ed. 2008 Curse of the Black Gold: 50 Years of Oil in the Niger Delta. Brooklyn NY: Powerhouse Books.

Wright EO (2010) Envisaging Real Utopias. New York: Verso. 